\title{
The Symbol of the Centre and its religious function in Islam
}

\author{
By JAN HJÄRPE
}

A modern catechism for English-speaking Muslim children contains a map showing Mecca as the Centre of the inhabited world ${ }^{1}$-just as the old Arab geographers, e.g. Ibn Hawkal, begin their descriptions of cities and countries with "the mother of cities" (cf. Sura 42:7/5), Mecca' ${ }^{2}$. Eliade cites the feeling of a-homogeneity in space as a basic religious experience ${ }^{3}$. Separate parts of a room, different places, regions and directions have different emotional values in the eyes of the individual. There is a ritual orientation in the world. In this context we may speak of a Centre, the Origo in the religious orientation in the world. This concept is an essential feature of Islam. To be valid the prayers must be performed facing the kibla, which is the Ka ${ }^{c} \mathrm{ba}$ in $\mathrm{Mecca}^{4}$. The animal to be slaughtered stands with its head towards the kibla ${ }^{5}$, the dead is buried with his face towards Mecca. The kibla determines the orientation of the mosques, and thus indirectly, town plans throught the Muslim world. Mecca is also the goal of the Pilgrimage.

In bygone days the Muslim traveller carried an astrolabe to find the kibla with the help of the stars ${ }^{6}$; today a special compass is used. The kibla, the direction for ritual acts, is towards the Centre of the world, the $\mathrm{Ka}^{\circ} \mathrm{ba}$ in Mecca, or, to be exact, towards the north-western wall of the $\mathrm{Ka}^{\circ} \mathrm{ba}$ building between the western corner and the gilded spout for the rainwater from the roof ${ }^{7}$.

Mecca's unique position and the sanctity of the $\mathrm{Ka}^{\mathrm{c}} \mathrm{ba}$ are well evidenced in the Koran": "Behold! The first temple (bayt) that was founded for mankind, was that in Bakka, blessed, and a guidance to the worlds. In it are evident signs, the place of Abraham (makām Ibrāhim ), and he who enters it is safe. And it is incumbent on the humans before God to make the pilgrimage to the temple, everyone who is able to do it." (Sura 3:96/90 f.)

The difference between an object as a religious symbol and a neutral and

1 Cf. Toto 69.

${ }^{2}$ Cf. Ibn Hawkal $17 \mathrm{f}$. and $23 \mathrm{ff}$.

${ }^{3}$ Cf. Eliade $1957,13 \mathrm{f}$.

${ }^{4}$ Cf. Wensinck 1965,260 f. The Koranic rule is found in Sura 2: 142/136, 148/143-150/145.

${ }^{5} \mathrm{Cf}$. Bousquet 213.

${ }^{6}$ Cf. Arnold 114.
7 Cf. Wensinck 1965, 260, and Wensinck $1974,318$.

8 The most important passages in the Koran concerning the $\mathrm{Ka}{ }^{\circ} \mathrm{ba}$ and Mecca are: $2: 144 / 139, \quad 149 / 145,150 / 145,217 / 214$, $3: 96 / 90-97 / 92, \quad 5: 97 / 98, \quad 22: 29 / 30,33 / 34$, 27:91/93, 28:57, 29:67, 42: 7/5, and 107:3. 
profane object is the ritual behaviour: it attracts rituals and observances which are justified and explained by religious belief. The term Symbol of the Centre has been used freely by Eliade and his followers ${ }^{9}$. My use of the term does not imply acceptance of Eliade's interpretation of the phenomenon, i.e. the significance and function which he attributes to it. The Centre, in this case, is a specific object, the $\mathrm{Ka}^{\mathrm{c}} \mathrm{ba}$, and, to a certain extent, the city of Mecca as a whole, in their character of focus in the ritual geography of Islam. In what way is the $\mathrm{Ka}^{\circ} \mathrm{ba}$ (and Mecca) as the Centre of the Muslim world a symbol? What is the value of the symbol today? In short: What is the religious function of the Symbol of the Centre in Islam in the 1970's?

"Orientalist" is an invective in the mouth of a Muslim. The interest of the Western Orientalist in regard to the $\mathrm{Ka}$ cba, and the ritual of the Pilgrimage, was primarily to search for their "original", i.e. pre-Islamic, significance ${ }^{10}$. Such studies provoke the repugnance of the Muslim who happens to read them. He maintains, perhaps rightfully, that the orientalist who uses this method cannot discern the real meaning and function of the phenomenon, i.e. its meaning for, and function among, those who profess and practice the religion today. Speculations on the possible "solar character" of the pre-Islamic rites, or whether they constituted "rainrituals", are of no interest in this connexion. We may also disregard the folklore about the $\mathrm{Ka}{ }^{\text {'ba, insofar }}$ as such material does not in one way or another occur in contemporary sources $^{11}$. In Islam today these legends play a very insignificant role. They are often explicitly repudiated.

Source material:

(a) Modern guide-books (manāsik) for pilgrims to Mecca. Here we often find interpretations of the significance of the different rites, and prayers and precepts indicating the meaning of the different objects and modes of behaviour for the believer.

(b) Tracts and booklets from the Islamic $d a^{e} w a$ (mission); information, apologetics and propaganda addressed to Muslims and non-Muslims in the west.

(c) Accounts by pilgrims of their experiences and reactions.

(d) Muslim publications, speeches, articles etc. which illustrate the role of the Ka ${ }^{\text {ba }}$ and of Mecca.

(e) Material which gives information on events in Mecca: Islamic papers, journals, the publications of the Haji Research Centre (created in 1975) of the Abdulaziz University, official statistics etc.

Comparative material from earlier times is to be found in abundance in Sir Richard Burton's famous Pilgrimage to al-Madinah and Meccah. Burton's

${ }^{9}$ Cf. Eliade 1952, $4 \mathrm{ff}$; Eliade $1949 a, 19$, $30 \mathrm{ff}$; Eliade 1957, $23 \mathrm{f}$.

${ }^{10} \mathrm{Cf}$. e.g. Chelhod $204 \mathrm{f}$, and $209 \mathrm{ff}$.
11 Myths and legends about the $\mathrm{Ka} \mathrm{a}^{\circ} \mathrm{ba}$, cf. Chelhod 232. 
own thorough observations are derived from his activity as a spy in al-Hidjāz in the $1850^{\prime}$ 's.

The sanctity and unique status of Mecca and of the $\mathrm{Ka}^{\mathrm{c}} \mathrm{ba}$ is indicated by the right of asylum: "He who enters it is safe" (Sura 3:97/91, cf. 28: 57 and 29:67). al-Haram is inviolable, but its right of asylum is not without limitations. It is not valid for unbelievers who attack Muslims (Sura 2:191/187), and a criminal who seeks refuge there must not be offered food, so that he must soon surrender ${ }^{12}$. The inviolability also holds good for flora and fauna. Plants and animals (with certain exceptions) are protected within the Haram of $\mathrm{Mecca}^{13}$. The ritual slaughter during the Pilgrimage is performed not at the $\mathrm{Ka}^{\mathrm{c}}$ ba (as the Koran implies: Sura 22:33/34) but in Minā. One result of the ban on the killing of animals is the abundance of pigeons at the Mosque of Mecca. Folklore has many legends about these pigeons ${ }^{14}$.

Due to the religious importance of Mecca strangers have settled there ${ }^{15}$. Mecca has become a Muslim world in miniature. All ethnic groups and nationalities in Islam are to be found there ${ }^{16}$. Saudi Arabia is now one of the world's major countries of immigration and severe restrictions on illegal immigration have recently been initiated ${ }^{17}$. Mecca is now a large city. In 1853 Burton estimated the population as $30-40,000^{18}$, excluding pilgrims, while now the number is reported to be $301,000^{19}$. Many gather in Mecca, devotees invariably congregate around the $\mathrm{Ka}{ }^{\circ} \mathrm{ba}$, night and day, not only to perform the rites of hadjdj and umra, but for prayer and devotion. Zaki Badawi says (in 1978): "The sound of their pleading voices and the patter of their hurrying feet fills the heart with awe. No place on earth inspires such a profound experience." 20

The $\mathrm{Ka}^{\mathrm{c}} \mathrm{ba}$ 's role as an object of devotion is also indicated by the fact that pictures of the temple actually serve as "devotional icons", in homes and in mosques. We can even see a tendency for a stylized image of the $\mathrm{Ka}^{\mathrm{c}}$ ba to replace the crescent as the symbol of Islam, i.e. the Symbol of the Centre tends to become the symbol of the religion as a whole. We may also note that the imàm of the $\mathrm{Ka}^{c} \mathrm{ba}$ (at present Shaykh Abdulaziz b. Abdullah) is a personage of importance, leading diplomatic delegations etc. During a world tour he visited Great Britain in March 197821, and at the Asian Islamic Conference in Karachi 6-8 July 1978 he led 1,5 million persons in the Friday prayers $^{22}$.

As goal for the Pilgrimage Mecca is more important than ever before. At the hadjdj in 1807 Ali Bey estimated the number of pilgrims at $83,000^{23}$, and

\footnotetext{
12 Cf. Hajj 17.

13 Cf. Wensinck 1974, 322.

14 Cf. Burton 2, $174 \mathrm{f}$.

15 Cf. Makky 23.

16 Cf. Hajj $124 \mathrm{ff}$.

${ }^{17}$ Cf. Impact 8: 14, 4.

${ }^{18}$ Cf. Burton 2, 229, note 1 .
}
19 Cf. Whitaker's 933.
20 Hajj 18.
21 Cf. Impact 8:3, 5 and 8:4, 15.
22 According to a notice in Impact 8: 14, 4. The number may be exaggerated.
${ }_{23}$ Statistics for the 19 th century, cf. Burton 2,188 .


the maximum number recorded in the 19 th century was 160,000 . Between 1957 and 1962 there were 140-180,000 pilgrims per annum ${ }^{24}$. In 1964 the number (excluding residents in Saudi Arabia) was 260,000, and in 1969 $375,000^{25}$. Now we find still higher figures: In 1976719,040 individuals obtained visas for pilgrimage ${ }^{26}$, and in November 1977 the Saudi Arabian officials issued permits to 739,319 persons ${ }^{27}$. To this figure we must add the pilgrims already residing in Arabia, who do not need visa. In all, about 1,5 million persons perform the pilgrimage (hadjdj and ${ }^{c} u m r a$ ) each year ${ }^{28}$.

There are several factors behind this enormous increase in numbers: health services which reduce the risk of epidemics to a minimum, modern communications ( $2 / 3$ of the pilgrims arrive by air $)^{29}$, security on the roads, and, of course, the moderate cost of travelling ${ }^{30}$. We may also consider the Pilgrims' service developed under the active supervision of the Saudi Arabian government, and the careful administration of all the details associated with the Pilgrimage ${ }^{31}$. Several Muslim governments provide facilities for the pilgrims in the form of public travel agencies etc. In other cases they try to limit the number of participants, particularly because of economic implications $^{32}$. The pilgrimage to Mecca plays a major role in the co-operation between Muslim countries in the fields of religion, economics and politics ${ }^{33}$. The Symbol of the Centre has become a token of the political significance of Islam.

One and one half million persons perform the prescribed rites during the short period of the hadjdj. The great problem is congestion. Soon the limit will be reached when the topography itself will prevent further increase. The authorities have discussed the possibility of blasting parts of the surrounding mountains to provide more space. Some blasting has been done (for roads etc.), but the making of substantial alterations in the topography of the Sacred City is adjudged unduly provocative.

The reverence for the symbol is indicated also by the splendour of the Mosque. The most important change in Mecca is the reconstruction of the Mosque around the $\mathrm{Ka}^{\mathrm{c}} \mathrm{ba}$ - the $\mathrm{Ka}^{\mathrm{c}}$ ba itself of course remains intact ${ }^{34}$. The "Mosque [improvement] project" was begun in Mecca in 1952 (and in Medina in 1955$)^{35}$. In Mecca more than 2,400 houses were purchased and

${ }^{24}$ Cf. Wensinck 1971, 34.

${ }^{25}$ Cf. Holter 201, 35.

${ }^{26}$ Cf. MENA 614; Impact 7:23, 4.

${ }^{27}$ Cf. Impact $7: 23,4$.

${ }^{28}$ For the proportions between different nationalities, see Hajj 111.

${ }^{29}$ Cf. Impact 7: 23, 4.

${ }^{30}$ Advertisement for hadjdj and for 'umra are to be found in every number of Impact, and in many other Muslim journals.

${ }^{31}$ For the actual administration of the Pilgrimage, cf. Haij $59 \mathrm{ff}$. and $87 \mathrm{ff}$.
${ }^{32}$ In 1978 e.g. Nigeria, Pakistan and Turkey, cf. Impact 8: 14, 14, 8:15, 4 and 15. See also Ali Bhutto IV.

${ }^{33} \mathrm{Cf}$. Sicard $350 \mathrm{ff}$.

${ }^{34}$ For detailed descriptions of the $\mathrm{Ka}{ }^{\circ} \mathrm{ba}$, cf. Wensinck 1974, $317 \mathrm{ff}$. See also Burton, 2, $294 \mathrm{ff}$., for comparative material from the 19 th century.

${ }^{35}$ Cf. Makky 43 and MENA 30. 
demolished to provide space for the enlargement of the Mosque and for new open places and roads ${ }^{36}$. New two-storey galleries were built around the old mosque, so that since 1976, when the reconstruction was completed al-Masdjid al-Haräm covers 19 hectares (earlier: 2.9 hectares). A protruding wing, $395 \mathrm{~m}$ in length, covers al-Mas ${ }^{e} \bar{a}$, the way between al-Marwa and as-Șafā hills. The Mosque is equipped with seven minarets, $92 \mathrm{~m}$ in height ${ }^{37}$. Some changes have been made in the inner court of the mosque, including the demolition of the pavilions for the imāms of the four madhähib, one of which was the old superstructure of the Zamzam well, the makäm Ibrähim has a new $k u b b a$ etc. ${ }^{38}$.

The central parts of Mecca were considerably changed ${ }^{39}$ by the reconstruction of the Mosque, by the new open places around it, and by the new modern buildings up to 13 storeys high which have been erected nearby. The new houses and streets have not provoked universal satisfaction among Muslim architects and town planners. They find that the constructions impair Mecca's character of a Muslim city. They have an adverse effect on the spiritual experience of the Centre of Islam, in that Mecca tends to resemble any major city of glass and concrete ${ }^{40}$. The symbol loses some of its impact. Material prosperity is not entirely a good thing: The devotion, the spiritual benefit of the Pilgrimage and the sojourn at the Centre is impaired by such disturbing elements as the noise from cars and aeroplanes, the smell of exhaust gases-and "the horrific music of the transistors", and "In present-day Muna what is experienced is not the environment of the Prophet, but the surroundings of Manhattan ..."41.

The benefits of modern technology, the facilities provided for the pilgrims, and the rigorous prohibition of non-Muslims approaching Mecca, are all intended to promote the devotion, the experience of "being there". But, as the specialists of the Hajj Research Centre emphasize, the Pilgrimage must not become too easy, for the spiritual benefit will be destroyed. Hadjdj must not resemble a common picnic ${ }^{42}$.

The great influx of pilgrims was surely the main reason for the demolition of the pavilions belonging to the imāms of the four madhähib at the $\mathrm{Ka}^{\mathrm{c}} \mathrm{ba}^{43}$, but this was also an expression of ideology: It emphasizes that every form of "secterianism" contravenes the true nature of Islam. The Centre ought to stand for unity. Likewise the old antagonism against the $\operatorname{sh}^{\mathrm{e}} a$ is modified-or even declared nonexistent ${ }^{44}$.

Changes in rites and in behaviour can be studied by comparison with Burton's detailed descriptions from the pilgrimage of 1853 . Since the Saudi

36 Cf. Makky 45.

37 Cf. ib. $41 \mathrm{f}$.

38 Cf. the illustrations in Makky, 10, and Plates 6 A, 8 A; Ayyūb 345, 349.

39 Cf. Makky $27 \mathrm{ff}$.

${ }^{40}$ Cf. Hajj 36 f. also 22.
41 Ziauddin Sardar in $\mathrm{Hajj} 35$.

${ }^{42}$ Cf. ib. 1, 24 f., 33 f.

43 Cf. Wensinck 1974, 318.

44 In conversations with educated Muslims I encountered the response that no antagonism ever existed between sunnis and shi ${ }^{i} i s$. 
conquest of al-Hidjāz in the 1920 's, the rigid principles of the hanbalite madhhab have resulted in a reformation, an eradication of many former customs associated with the Pilgrimage, above all the visits to the tombs of saints and the rites there, and to the various places which popular tradition connected with different incidents in the life of the Prophet ${ }^{45}$. Here the wahhābis made a clean sweep ${ }^{46}$. This means, in fact, that the traditions connecting Abraham with Mecca, founded on the Koran, are more accentuated today, and the traditions about Muhammad and Mecca are less stressed, perhaps not in theory, but in practice, in ritual. The commemoration in acts (=the rites) concerns the memory of the "father of the Prophets", Abraham. When now other rites, connected with the saints and with the life of Muhammad are abolished, the psychological effect is that Muhammad is displaced by Abraham and his family at the Centre of Islam. The old popular legends connecting Adam with the $\mathrm{Ka}^{\mathrm{C}} \mathrm{ba}^{47}$ are seldom mentioned today, at least not expressis verbis, although they are implicit, e.g.: "There are reports which take the Haij further back in history and associate it with man's first steps on this planet" 48 .

It is possible, however, that the quotation refers to the ritual at "Arafāt, and not to the $\mathrm{Ka}^{\mathrm{c}}$ ba and Mecca.

Muslims from all over the world gather in Mecca. They meet fellow-believers, all in the same clothing, performing the same rituals. It is often emphasized that the brotherhood, the unity and the equality of Islam are there made manifest as tangible experiences ${ }^{49}$ which the Muslim should apply in his daily life ${ }^{50}$. Seyyid Hossein Nasr says: "Something of the Centre is thus [by the return home] disseminated in the periphery and through this yearly act the whole of the Muslim community is purified." 51

The rites and the events of the Pilgrimage are followed by those remaining at home, by means of press, radio and (since 1973) $\mathrm{TV}^{52}$, and by the narratives of those who return. The social status of the $h \bar{a} d j d j \bar{l}$ is worth the effort.

Political leaders meet in Mecca and combine political conferences with the performance of the $u m r a^{53}$. Governments send deputations to the hadjdj $^{54}$. An official delegation of Muslims from the Soviet Union-20 religious officials-made the Pilgrimage for the first time in November $1977^{55}$. The visit was evidently part of the attempt to abate the antagonism of the Muslim world against the Soviet Union, and it testifies to the political

\footnotetext{
45 For these cult-sites in Mecca, cf. Buiton 2, $248 \mathrm{ff}$, , $250 \mathrm{ff}$, esp. $253 \mathrm{f}$. Not even the mawlid of Muhammad is observed in Saudi Arabia today.

${ }^{46} \mathrm{Cf}$. Moh. Jamil Brownson in Hajj 122.

${ }_{47}$ Cf. Seligsohn 14.

48 Hajj 15.

${ }^{49}$ Cf. Ahsan 20; Häj 86, Nasr 116.
}

50 Cf. Pilgrimage 8.

51 Nasr 116.

${ }^{52}$ Cf. Wensinck 1971, 31; Holter 15.

53 So e.g. al-Kadhdhāfī and Anwar as-Sādāt in 1974 (cf. al-Kadhdhāfi 80 and 111) and Sekou Toure in 1978 (Impact 8: 13, 2).

${ }^{54}$ Cf. Holter 203.

55 Cf. Impact $7: 24,15 ; 8: 3,5$. 
importance of the symbolic centre of Islam. The possession of al-Hidjāz gives Saudi Arabia considerable religio-political prestige, and the income from the oilfields allows of its exploitation. Symbolically this is indicated by the fact that nowadays Saudi Arabia, and not as previously, Egypt, supplies the Ka ba with its Kiswa, the beautifully embroidered black curtain ${ }^{56}$.

Mecca, the conference centre of the Muslim world, the meeting-place, the symbol of the supranational nature of Islam-all this is frequently re-iterated in 20th century Islam ${ }^{57}$. Therefore it is quite natural that Rábitat al- ${ }^{\circ} \bar{a}$ lam al-islāmì (Muslim World League) has it headquarters in Mecca. The Räbita intends to erect its big new printing-house "near the Ka'ba to serve the needs of $d a^{\text {e }} w a$ (mission) throughout the world" 58 .

The Ka ba and the Haram of Mecca are not involved in the most important and constitutive rite of the hadjdj: al-wuküf, "the standing", at "Arafāt ${ }^{59}$, in commemoration of the meeting between Adam and Eve ${ }^{60}$ and of Muhammad's Farewell Sermon ${ }^{61}$. But an important rite in both hadjdj and 'umra is the tawäf, the ritual circumambulation of the $\mathrm{Ka}^{c} \mathrm{ba}^{62}$. The tawäf is performed anti-clockwise seven times, with the corner of the Black Stone as the starting-point. Circumambulation anti-clockwise is normally considered the more unusual form of the phenomenon in the world of religions; the Hindu pradaksinam is performed clockwise ${ }^{63}$ with the Centre to the right, but circumambulation in the opposite direction is to be found in tantric Buddhism and in the Tibetan Bön-religion. We may also note that in the Christian liturgical tradition the priest turns with his heart towards the altar, i.e. with the Centre to the left.

It is almost a dogma, since Mannhardt, to interpret ceremonial circumambulation as a solar ritual ${ }^{64}$. I have found no indications whatsoever of a connexion between tawäf and the sun, at least not in contemporary material. Insofar as any interpretation of the rite is given, it is called an act of obedience towards God ${ }^{65}$, or expressing honour to Abraham's God ${ }^{66}$. The rite, like the whole ritual of the Pilgrimage, is regarded as instituted by Abraham. The centre which is circumambulated is Abraham's temple ${ }^{67}$.

The tawa $f$ of departure is the concluding rite in both hadjdj and 'umbra, performed immediately before the pilgrim leaves Mecca ${ }^{68}$. Expressions of

56 Cf. Wensinck 1974, 317.

57 See e.g. Haijj 122, an-Nășir, the concluding paragraph, Baljon 80; Ahsan 20 .

58 Impact 8: 8, 15.

${ }^{59}$ Cf. Sardar in Haij 31; Makky 40. For the ritual there, cf. Ay yūb, $167 \mathrm{ff}$., Kamāl $68 \mathrm{ff}$.

${ }^{60}$ Cf. Burton 2, $188 \mathrm{f}$., Sardar in Haij 31; Wensinck 1960, 604.

${ }^{61}$ For Muhammad's sermon and his "standing" on the mount, see Ibn Hishām $968 \mathrm{ff}$.; cf. Makky 40.

${ }^{62}$ Ritual and prayers for the țawāf: cf. Ayyūb
135 ff. Kamāl 35 ff. (transl. 43 ff.), see also Buhl $583 \mathrm{f}$.; Burton 2, $161 \mathrm{ff}$.

${ }^{69} \mathrm{Cf}$. Bolle 129.

${ }^{64}$ Cf. d'Alviella 658.

${ }^{65}$ Cf. Hajj 31.

${ }^{66}$ Cf. ib. 16.

${ }^{67}$ The most important passage in the Koran connecting Abraham with the Pilgrimage is Sura 22:26/27-37/38. On Abraham and Ishmael as the builders of the Ka ${ }^{\mathrm{c}} \mathrm{ba}$, see Sura 2: 127/121., cf. Hjärpe $386 \mathrm{f}$.

${ }^{68}$ Cf. Ayyūb 148 f. 
strong emotional involvement follow the performance of this rite ${ }^{69}$. Between the eastern corner and the door of the $\mathrm{Ka}^{\mathrm{c}} \mathrm{ba}$ extends the part of the north-eastern wall known as al-Multazam, where the visitors press breast and face against the wall, their arms above their heads ${ }^{70}$, beseeching "the good things of this and the other world"71. This rite can perhaps be termed "glissade" 72 , but to call it magic would be wrong. Often it is the expression of a strong emotional experience ${ }^{73}$.

Makām Ibrähim is a stone north-east of the Ka ba. Tradition says that Abraham stood on this stone when building the temple ${ }^{74}$. The Zamzam well, east of the $\mathrm{Ka}^{\mathrm{c}} \mathrm{ba}$, is by tradition the source which saved the life of Ishmael when he and his mother Hagar searched for water in the barren valley. Its water was formerly considered miraculous, curing all manner of ills ${ }^{75}$. One seldom finds such statements today, or at least not in print. The connection between the family of Abraham and the Pilgrimage is accentuated by other ceremonies: $S a^{c} y$, the "course" between aș-Șafā and al-Marwa ${ }^{76}$ commemorates Hagar's search for water". The "stoning of Satan" in Minä78 recalls Abraham's rejection of Satan's temptation to disobey God's command to offer his son. The implication of the ceremony is that the pilgrim renounces evil, and is ready to fight against temptations ${ }^{79}$. The rite of slaughtering in Mina $\bar{a}^{80}$ — which coincides with the celebration of " $\bar{I} d$ al-adha throughout the Muslim world ${ }^{81}$-derives from the legend of Abraham's sacrifice (Sura: 37: 102/100-107) and commemorates his obedience ${ }^{82}$. The significance of the rite is stated to be the manifestation of willingness to renounce, to sacrifice one's property (or even one's life). It is also said to remind the pilgrim of his duty to help the needy ${ }^{83}$. The rite is a repetition, says Eliade, it "repeats an act performed at the beginning of time by a god, a hero, or an ancestor" The hadjdj (and also the "umra) is a "repetition" in two stages: The norm and model for the Pilgrimage is Muhammad's Farewell hadjdj ${ }^{85}$. To perform the ritual at the Centre is to follow in the footsteps of the Prophet ${ }^{86}$. But the vital and conclusive aition thereof are the traditions about Abraham. The pilgrim "feels outside his time and space, back in the era of Abraham and

${ }^{69}$ Cf. e.g. Burton 2, 284, note 2.

${ }^{70}$ Cf. Ayyūb 151; Kamāl 43 f. (transl. 51 f.);

Wensinck 1974, 318; Burton 2, 166, 169.

7 Ayyüb 151; cf. Kamäl 43 f. (transl. 51 f.).

${ }^{72}$ Cf. Eliade 1949, $196 \mathrm{ff}$.

73 Cf. Burton 2, 173, 176.

${ }^{74}$ Cf. Hajj 20.

${ }^{75}$ Cf. Chelhod 233; Wensinck 1974, 321.

${ }^{76}$ The rules for $a s-s a^{c} y$ : cf. Ayyūb $152 \mathrm{ff}$., see also Kamāl $53 \mathrm{ff}$. (transl. 56 ff.); Burton 2, $288 \mathrm{f}$.

77 Cf. $H a j j 30,40$.

78 The rules for ar-ramy, cf. Ayyüb $191 \mathrm{ff}$. See also Burton 2, 203, 219, 222, note 1, 291.
${ }^{79}$ Cf. Makky 40, Haij 16, 32.

${ }^{80}$ The rules for the slaughter: cf. Ayyūb 205,

$231 \mathrm{ff}$. See also Burton 2, $217 \mathrm{ff}$, , 291.

81 Cf. Muslim $7 \mathrm{ff}$.

${ }^{82}$ Cf. Hamīdullāh to Sura $37: 102,107 ; H a j j$ 32.

${ }^{83}$ Cf. Ahsan 20, 25; Makky 41. Notice also as-Sādāts "sacrifice", his visit to Jerusalem at the "I $d$ in 1977 and the allusions to Abraham's sacrifice in his speech in the Israeli parliament (as-Sădät 310, 333).

${ }^{84}$ Eliade 1949a, 22.

85 Cf. Haij 55.

${ }_{86}$ Cf. ib. 35, 117; Pilgrimage 8. 
the sacred family" ${ }^{\prime 87}$. The connection between Abraham and the $\mathrm{Ka}^{\mathrm{e}} \mathrm{ba}$ is seen as an essential factor. We can, for instance, point to the famous Taha Husayn affair in the 1920's. He was guilty of the enormous heresy of doubting the historicity (from a strict scholarly point of view) of Abraham's visit to Mecca. This caused his dismissal from his post as a university teacher ${ }^{88}$.

Many have testified that the Pilgrimage, nay, already the mere sight of $\mathrm{Ka}{ }^{\mathrm{b}} \mathrm{ba}$, can provoke extremely strong feelings. It is described as a deep religious experience, a source of spiritual joy, a "rebirth" 89 . Burton mentions that at the $\mathrm{Ka}^{\mathrm{c}}$ ba he witnessed a case of a malbüs (a person in a state of religious ecstacy or frenzy) ${ }^{90}$. S. H. Nasr says that "the pilgrimage means to journey from the surface to the centre of one's being for, as so many Sufis have said, the heart is the spiritual $\mathrm{Ka}^{\mathrm{c}} \mathrm{ba}$." ${ }_{11}$

Hjalmar Sundén states that in psychological terms the $\mathrm{Ka}^{\mathrm{a}} \mathrm{ba}$ can be regarded as a Mother symbol. The pre-Islamic cult of the three goddesses at the $\mathrm{Ka} \mathrm{a}^{\mathrm{b}}$ a has disappeared, but the $\mathrm{Ka}^{\mathrm{c}}$ ba itself is preserved. The temple itself can in the patriarchal religion of Islam satisfy the unconscious (subconscious) longing for the "Mother": "Thus the Pilgrimage to the Ka"ba appears in depth-psychological perspective as an extraordinarily important factor for the establishment of the psychical balance which, according to many observers, is a characteristic of Islam's devotees." 92

The Black Stone-never mentioned in the Koran-is regarded as the remnant of Abraham's and Ishmael's Ka ${ }^{\circ} \mathrm{ba}^{93}$. Sometimes it is associated with the "covenant" between God and the children of Adam (cf. Sura $7: 172 / 171)$. In old Islamic folklore this "covenant" and its connection with the $\mathrm{Ka}^{\mathrm{c}} \mathrm{ba}$ was expressed in terms of a myth: The $\mathrm{Ka} \mathrm{c}^{\mathrm{c}}$ ba has eaten the parchment on which the contract was written ${ }^{94}$; thus the $\mathrm{Ka}^{c} \mathrm{ba}$ is the witness of the covenant. Such stories are not told today, but the point remains, in a demythologized form: The Black Stone is, says S. H. Nasr, a symbol of this original covenant, a symbol of the burden which God imposed on Man, the responsibility, the faculty to choose obedience or disobedience ${ }^{95}$. The $\mathrm{Ka}^{\mathrm{c}} \mathrm{ba}$ is regarded as "the very symbol of monotheistic belief', says Zaki Badawi ${ }^{96}$.

The $\mathrm{Ka} \mathrm{c}^{\mathrm{b} a}$, and Mecca, is the Centre of Islam's "topographical religiosity". The Symbol of the Centre in Islam is, on the one hand, the tangible object, the City and the temple, and on the other the ritual behaviour concerned with the Centre, i.e. tawäf, kibla etc. The symbol is efficacious, it has psychological effects, it provokes and expresses emotions, spiritual

\footnotetext{
${ }^{87}$ Haij 24; cf. Makky 21 ff.; Hajj 15.

${ }^{88}$ Cf. Ahmad $45 \mathrm{ff} ;$; Wessels 4, note 21 .

${ }^{89}$ Cf. Hajj 9, 18, Pilgrimage 6; Burton 2, 152, 161.

90 Cf. Burton 2, 175.

91 Nasr 117.
}

92 Sundén 458.

${ }^{93}$ Cf. Pilgrimage 4.

94 Cf. Chelhod 205.

95 Cf. Nasr 26, 41.

96 Hajj 15. 
experiences, feelings of fellowship, of duties towards God and fellow-believers; not only do these emotions visualize fundamental principles in Islam, but by the experience of the Symbol these ideas are integrated in the personality of the individual (or rather: of millions of individuals!), with social and political consequences for his actions. The fact that the Centre is invariably remembered as the kibla, the direction of the daily ritual behaviour, creates a profound awareness of membership of a community transcending ethnic, national and political boundaries.

\section{Bibliography}

EI Ency clopaedia of Islam.

ERE Encyclopaedia of religion and ethics.

MENA The Middle East and North Africa.

SEI Shorter encyclopaedia of Islam.

TRE Theologische Realenzyklopädie.

Ahmad, M., 1963, Die Auseinandersetzung zwischen al-Azhar und der modernistischen Bewegung in Ägypten von M. 'Abduh bis zur Gegenwart. Hamburg.

Ahsan, M., 1977, Islam, faith and practice. Leicester.

Ali Bhutto, Z., 1976, Thoughts on some aspects of Islam. Lahore.

d'Alviella, G., 1910, Circumambulation. ERE 3.

Arnold, T.-Guillaume, A., 1965, The legacy of Islam. Oxford.

Ayyūb, H., 1973, al-Hadjdj fíl-islām. Kuwait.

Baljon, J., 1961, Modern Muslim Koran interpretation. Leiden.

Bolle, K., 1969, Speaking of a place. Myths and symbols, studies in honor of Mircea Eliade. Chicago.

Bousquet, G., 1965, Dhabīha. EI 2.

Buhl, F., 1965, Țawāf. SEI.

Burton, R., 1893, Personal narrative of a pilgrimage to al-Madinah and Meccah 1-2, Memorial edition. London.

Chelhod, J., 1964, Les structures du sacré chez les arabes. Paris.

Eliade, M., 1949, Traité d'histoire des religions. Paris.

- 1949 a, Le mythe de l'éternel retour. Paris.

- 1952, Images et symboles. Paris.

- 1957, Das Heilige und das Profane. Hamburg.

Hajj, 1978, Hajj studies 1. London-Jeddah.

Hamìdullāh, M., 1973, al-Kur ān al-madjīd (Le Saint Coran). Ankara.

Hjärpe, J., 1976, Abraham, religionsgeschichtlich. TRE 1.

Holter, A., 1976, Arabisk statsreligion. Oslo.

Ibn Hawḳal, A., 1872 f., al-Masālik wa'l-mamälik. Ed. M. de Goeje. Leiden.

Ibn Hishām, A., 1858 ff., Sìratu sayyidinā Muhammad. Ed. F. Wüstenfeld. Göttingen.

Impact, $1977 \mathrm{f}$, Impact International fortnightly, Muslim viewpoints on current affairs.

al-Kadhdhāfi, M., 1975, Discourses by Mu'ammar el-Qathafi. S.1.

Kamāl, A., 1964, The sacred journey. ar-Rihla al-mukaddasa [1960]. London.

Makky, G., 1978, Mecca, the pilgrimage city, a study of pilgrim accommodation. London.

MENA, 1977-1978.

Muslim, s.a., Muslim festivals and ceremonies. Croydon. 
an-Nāṣir, G. [Nasser], 1970, Falsafat ath-thawra. al-Kāhira.

Nasr, S., 1975, Ideals and realities of Islam. London.

Pilgrimage, 1975, Pilgrimage, hajj. Croydon.

as-Sādāt [el-Sadat], A., 1978, In search of identity. London.

Seligsohn, M., 1961, Ādam. SEI.

Sicard, S., 1976, Contemporary Islam and its world mission. Missiology.

Sundén, H., 1966, Religionen och rollerna. Stockholm.

Toto, O., 1973, Children's book on Islam and the last prophet of God Muhammad. London.

Wensinck, A., 1965, Kibla. SEI.

Wensinck, A., Gibb, H., 1960, 'Arafa. EI 1.

Wensinck, A., Jomier, J., 1974, Ka' ba. EI 4.

Wensinck, A., Jomier, J., Lewis, B., 1971, Hadjdj. EI 3.

Wessels, A., 1972, A modern Arabic biography of Muhammad. Leiden.

Whitaker, 1976, Whitaker's Almanack 1977. London. 